\title{
PENGARUH TEMAN SEBAYA DAN PERSEPSI POLA ASUH ORANG TUA TERHADAP AGRESIVITAS SISWA DI SEKOLAH DASAR GUGUS SUGARDA
}

\author{
Sulistiyowati Budikuncoroningsih, \\ Program Studi Pendidikan Guru Sekolah Dasar \\ FKIP, Universitas Muhammadiyah Purwokerto \\ sulistiyowatibk@gmail.com
}

\begin{abstract}
This research was motivated by the existence of many students' aggressiveness problems. This research is aimed at finding out: 1) the influence of peers on students' aggressiveness; 2) the influence of parenting pattern on students' aggressiveness; 3) the influence of peers and perception of parenting pattern on students' aggressiveness. Quantitative approach with descriptive correlation was used as the research method. The population in this research was 245 students with 71 samples taken using proportionate stratified random sampling. Questionnaire was used to collect the data. Correlation formula of product moment, multiple correlation, simple regression and multiple regression were used to analyze the data. The result of the data showed that 1) there was a significant influence of peers on students' aggressiveness with the percentage of $12.8 \%$; 2 ) there was a significant influence of parenting pattern on students' aggressiveness with the percentage of $14.5 \%$; 3 ) there was a significant influence of peers and parenting pattern on students' aggressiveness with the percentage of $18.8 \%$.
\end{abstract}

\section{Keywords: Peers, Parenting Pattern, Students' Aggressiveness}

Abstrak. Penelitian ini dilatarbelakangi oleh banyaknya permasalahan agrevisitas yang dilakukan oleh siswa. Tujuan penelitian ini yaitu untuk mengetahui: 1) pengaruh teman sebaya terhadap agresivitas siswa; 2) pengaruh persepsi pola asuh orang tua terhadap agresivitas siswa; 3) pengaruh teman sebaya dan persepsi pola asuh orang tua terhadap agresivitas siswa. Penelitian ini menggunakan pendekatan kuantitatif metode korelasi deskriptif. Populasi penelitian ini berjumlah 245 siswa dengan 71 sampel yang diiambil menggunakan teknik proportionate stratified random sampling. Pengumpulan data yang yang digunakan pada penelitian ini yaitu berupa angket. Analisis data pada penelitian ini menggunakan rumus korelasi product moment, korelasi ganda, regresi sederhana dan regresi ganda. Hasil analisis data menunjukkan bahwa 1) terdapat pengaruh yang signifikan antara teman sebaya terhadap agresivitas siswa sebesar $12,8 \% ; 2$ ) terdapat pengaruh yang signifikan antara persepsi pola asuh orang tua terhadap agresivitas siswa sebesar 14,5\%; 3) terdapat pengaruh yang signifikan antara teman sebaya dan persepsi pola asuh orang tua terhadap agresivitas siswa sebesar $18,8 \%$.

Kata kunci: teman sebaya, persepsi pola asuh orang tua, agresivitas siswa

\section{PENDAHULUAN}

Tahap perkembangan terjadi pada setiap manusia terutama pada masa anak- anak. Tahap perkembangan yang terjadi pada anak umumnya sama. Perkembangan pada anak biasanya harus disesuaikan 
dengan lingkungannya, agar dia dapat menyesuaikan diri dan melaksanakan perilaku yang menjadi tugas perkembangannya dengan baik. Tugas dari perkembangan anak tentu tidak mudah, semakin besar tuntutan dan perubahan anak, semakin besar pula masalah yang dihadapi anak tersebut. Masalah-masalah tersebut akan membuat anak sulit untuk melakukan penyesuaian diri terhadap lingkungannya, sehingga mereka cenderung melakukan tindakan agresivitas seperti menyakiti orang lain baik fisik maupun verbal.

Agresivitas merupakan perilaku negatif yang terdapat pada individu, menurut Aronson (1972:98) agresivitas adalah tingkah laku yang dijalankan individu dengan maksud melukai ataupun tanpa tujuan tertentu. Tindakan agresivitas dapat dijumpai dimana saja termasuk di dalam sekolah. Lingkungan sekolah seharusnya dapat membentuk karakter dan perilaku siswa ke siswa arah yang lebih baik. Namun pada kenyataannya dalam berperilaku siswa tidak selalu sesuai dengan harapan, banyak siswa yang melakukan agresivitas seperti memalak, berkelahi, membolos, dan lain-lain.

Latar belakang agresivitas yang terjadi pada siswa dikarenakan beberapa hal diantaranya saat siswa berinteraksi dengan lingkungan, salah satu hal yang mempengaruhi agresivitas siswa adalah teman sebaya. Proses interaksi di lingkungan teman sebaya dapat ikut serta membentuk karakter siswa. Hal ini karena dengan berteman bersama orang yang seumuran akan mempengaruhi minat, pendapat, dan kepribadian. Baik buruknya pengaruh teman sebaya dapat disebabkan oleh keadaan lingkungan teman sebaya tersebut.

Lingkungan lainnya yang berpengaruh terhadap agresivitas siswa adalah keluarga, karena keluarga merupakan tempat awal pembentukan watak dan kepribadian siswa. Pembentukan watak dan keperibadian siswa tergantung pada pola asuh orang tua terhadap anak-anaknya. Baik buruknya perilaku siswa merupakan cerminan pola asuh yang orang tua terapkan, karena tindakan siswa dapat berawal dari menirukan perilaku orang tua yang dia lihat, dengar dan rasakan. Persepsi pola asuh orang tua yang salah dapat menyebabkan agresivitas pada siswa, seperti orang tua sering berkata kasar, berteriak atau memukul maka anaknya akan meniru dan dapat menjadi kebiasan.

\section{KAJIAN TEORI}

1. Teman Sebaya

Interaksi dengan teman sebaya merupakan permulaan hubungan persahabatan yang di dalamnya terdapat hubungan timbal balik. Santosa (2004:79) berpendapat "teman sebaya adalah kelompok anak sebaya yang sukses ketika anggotanya dapat berinteraksi. Hal-hal yang dialami oleh anak-anak tersebut adalah hal yang menyenangkan saja.Pergaulan diantara teman sebaya dapat mempengaruhi perilaku. Pengaruh tersebut dapat berupa pengaruh positif dan dapat pula berupa pengaruh negatif. Pengaruh positif yang dimaksud adalah ketika individu bersama teman-teman sebayanya melakukan aktifitas yang bermanfaat seperti membentuk kelompok belajar dan patuh pada norma-norma dalam masyarakat. Sedangkan pengaruh negatif yang dimaksudkan dapat berupa pelanggaran terhadap norma-norma sosial, dan pada lingkungan sekolah berupa pelanggaran terhadap aturan sekolah.

2. Persepsi Pola Asuh Orang Tua

Setiap orang pernah melakukan persepsi terhadap segala sesuatu yang dia lihat, dengar ataupun yang dia 
rasakan. Sugihartono dkk (2013:8) mengemukakan bahwa persepsi yaitu kemampuan otak dalam menerjemahkan stimulus. Persepsi tidak hanya dilakukan oleh orang dewasa, namun anak-anak juga melakukan persepsi terhadap sesuatu yang dia peroleh seperti pola asuh yang dilakukan oleh orang tuanya. Desmita (2009:144) menjelaskan bahwa pola asuh merupakan aspek yang sangat penting dalam hubungan orang tua dan anak. Menurut Ormrod (2008:94) pola asuh melibatkan hubungan antara orang tua dan karakteristik anak namun belum tentu menunjukkan hubungan sebab akibat. Jadi persepsi pola asuh orang tua adalah pengalaman yang diperoleh dari perlakuan orang tua yang diterapkan pada anak.

Keluarga menjadi tempat awal bagi perkembangan siswa. Hubungan yang positif dan sehat biasanya menghasilkan anak yang bahagia, ramah, dianggap menarik oleh oran lain dan relatif bebas dari kecemasan. Berbeda dengan anak yang mempunyai penyesuaian buruk yang biasanya berasal dari pola asuh orang tua yang tidak kurang tepat. Penyesuaian tersebut terjadi karena anak meniru gaya orang tua yang tidak baik atau kurangnya kasih sayang dari orang tua dan mempunyai hubungan yang kurang baik antara orang tua dengan anak.

Baumrind (Santosa, 2015:104-109) mengelompokkan 4 tipe pola asuh yaitu pola asuh authoritarian (otoriter), pola asuh permissive (permisif), pola asuh uninvolved (acuh tak acuh), orang tua uninvolved (acuh tak acuh) dan pola asuh authoritative (otoritatif).

3. Agresivitas Siswa

Menurut Patricia D Barry (Yosep, 2007:48) agresivitas adalah suatu keadaan emosi yang merupakan campuran perasaan frustasi dan benci atau marah. Agresivitas dapat dikatakan sebagai suatu perilaku yang dilakukan oleh seseorang dengan maksud untuk melukai atau menyakiti seseorang dengan sengaja.

Ormrod

(2008:176) yang menyatakan bahwa agresivitas dapat disebabkan oleh faktor internal maupun eksternal. Faktor internal meliputi kurang mampu melihat sudut pandang orang lain, kesalahan mengartikan syarat-syarat sosial, dominannya menguntungan diri sendiri, strategi pemecahan masalah sosial yang efektif dan keyakinan bertindak agresif itu tepat dan efektif. Faktor eksternal meliputi keluarga, sekolah dan teman sebaya. Faktor eksternal mempunyai pengaruh agresivitas yang berbedabeda, tinggi rendahnya agresivitas dapat dikarenakan dukungan yang mereka dapat dari lingkungannya.

Beberapa ahli mengklasifikasikan agresivitas ke dalam beberapa bagian salah satunya yaitu Buss dan Perry (1992:452-453) yang mengklasifikasi agresivitas mejadi empat bagian yaitu agresi fisik, agresi, kemarahan dan kebencian.

\section{METODE PENELITIAN}

Penelitian ini menggunakan pendekatan kuantitatif metode korelasi deskriptif. Penelitian ini dilaksanakan di Sekolah Dasar Gugus Sugarda Kecamatan Kalimanah yang terdiri dari SD N Babakan, SD N 1 Kalimanah Wetan, SD N 2 Klapasawit, SD N 1 Kalimanah Kulon, SD N 1 Klapasawit, SD N 1 Selabaya, SD N 2 Selabaya dan SD N 2 Kalimanah Wetan. Populasi penelitian ini yaitu seluruh siswa kelas V di Sekolah Dasar Gugus Sugarda yang berjumlah 245 siswa dengan 71 sampel yang diambil menggunakan teknik proportionate stratified random sampling. 
Teknik pengumpulan data yang yang digunakan pada penelitian ini yaitu angket atau kuesioner. Jenis angket yang diberikan kepada responden berupa angket tertutup. Analisis data untuk uji asumsi prasyarat yaitu menggunakan uji normalitas, homogenitas dan linearitas, sedangkan analisis data untuk uji hipotesis menggunakan rumus korelasi product moment, korelasi ganda, regresi sederhana dan regresi ganda yang berbantu SPSS versi 23.

\section{HASIL PENELITIAN}

\section{Uji Prasyarat}

a. Uji Normalitas

Uji normalitas bertujuan untuk menguji apakah data penelitian memiliki distribusi normal atau tidak. Hasil analisis data teman sebaya bersistribusi normal dimana $\mathrm{D}_{\text {hitung }}<\mathrm{D}_{\text {tabel }}$ atau 0,077 $<0,105$. Analisis data teman sebaya bersistribusi normal dimana $\mathrm{D}_{\text {hitung }}<$ $\mathrm{D}_{\text {tabel }}$ atau 0,076<0,105. Analisis uji normalitas data agresivitas berdistribusi normal dimana $\mathrm{D}_{\text {hitung }}$ $<\mathrm{D}_{\text {tabel }}$ atau 0,090<0,105.

b. Uji Homogenitas

Uji homogenitas dilakukan untuk mengetahui apakah data berasal dari populasi yang sama. Hasil analisis uji homogenitas diperoleh $\mathrm{F}_{\text {hitung }}=$ 1,594 dan $F_{\text {tabel }}=3.13$ sehingga $\mathrm{F}_{\text {hitung }} \leq \mathrm{F}_{\text {tabel }}$, maka $\mathrm{H}_{\mathrm{o}}$ diterima dan dapat disimpulkan bahwa data teman sebaya $\left(\mathrm{X}_{1}\right)$, persepsi pola asuh orang tua $\left(\mathrm{X}_{2}\right)$ dan agresivitas siswa $(\mathrm{Y})$ bersifat homogen.

c. Uji Linearitas

Uji linearitas digunakan untuk mengetahui apakah dua variabel mempunyai hubungan linear atau tidak. Analisis data teman teman sebaya $\left(X_{1}\right)$ berpola linear dimana $F_{\text {hitung }}<F_{\text {tabel }}$ atau 1,190
$<3,16$. Analisis data persepsi pola asuh orang tua $\left(X_{2}\right)$ juga berpola linear dimana $F_{\text {hitung }}<F_{\text {tabel }}$ atau $1,196<3,16$.

\section{Uji Hipotesis}

a. Pengaruh Teman Sebaya $\left(X_{1}\right)$ Terhadap Agresivitas Siswa (Y)

Hasil perhitungan korelasi product moment diatas menunjukan bahwa terdapat korelasi sebesar 0,396 antara teman sebaya dengan agresivitas siswa. Hasil uji signifikasi korelasi menunjukan bahwa terdapat hubungan yang signifikan antara variabel teman sebaya $\left(\mathrm{X}_{1}\right)$ dengan agresivitas siswa $(\mathrm{Y})$ dimana thitung $\geq t_{\text {tabel }}$ atau $3,584 \geq 1,995$. Persamaan regresi sederhana yang digunakan untuk memprediksi agresivitas siswa berdasarkan teman sebaya yaitu $\hat{Y}=34,82603+0,4396 X$. Hasil uji regresi sederhana menunjukan nilai $F_{\text {hitung }} \geq F_{\text {tabel }}$ atau $12,848 \geq 3,98$, maka Ho ditolak yang berarti bahwa terdapat pengaruh yang signifikan antara variabel teman sebaya dengan agresivitas siswa.

b. Pengaruh Persepsi Pola Asuh Orang Tua $\left(\mathrm{X}_{2}\right)$ Terhadap Agresivitas Siswa $(\mathrm{Y})$

Hasil perhitungan korelasi product monent di atas menunjukan bahwa terdapat korelasi sebesar 0,39689 antara variabel persepsi pola asuh orang tua $\left(\mathrm{X}_{2}\right)$ dengan agresivitas siswa $(\mathrm{Y})$. Hasil uji signifikasi korelasi menunjukan bahwa terdapat hubungan antara variabel persepsi pola asuh orang $\left(\mathrm{X}_{2}\right)$ dengan tua agresivitas siswa $(\mathrm{Y})$ dimana $t$ hitung $\geq t$ tabel atau $3,913 \geq 1,995$. Persamaan regresi yang digunakan untuk memprediksi agresivitas siswa berdasarkan persepsi pola asuh orang yaitu $\hat{Y}=28,5075+0,556 X$. Hasil uji regresi sederhana menunjukan nilai $F_{\text {hitung }} \geq F_{\text {tabel }}$ atau 12,9015 $\geq 3,98$, maka Ho ditolak yang berarti bahwa terdapat pengaruh yang signifikan antara 
variabel persepsi pola asuh orang dengan tua agresivitas siswa.

c. Pengaruh Teman Sebaya $\left(X_{1}\right)$ dan Persepsi Pola Asuh Orang Tua $\left(\mathrm{X}_{2}\right)$ Terhadap Agresivitas Siswa (Y)

Hasil perhitungan korelasi ganda di atas menunjukan bahwa terdapat korelasi sebesar 0,468 antara variabel teman sebaya $\left(X_{1}\right)$ dan persepsi pola asuh orang tua $\left(\mathrm{X}_{2}\right)$ dengan agresivitas siswa $(Y)$. Persamaan regresi gandanya yaitu $\widehat{Y}=15.843+0,306 X_{1}+0,388 X_{2}$. Hasil uji regresi ganda menunjukan nilai $F_{\text {hitung }}=9,534$ dan $F_{\text {tabel }}=3,132$ pada taraf signifikan $\alpha=0,05$ dan $\mathrm{db}=69$ sehingga Fhitung $\geq F_{\text {tabel }}$ atau 9,534 $\geq 3,132$, maka Ho ditolak yang berarti bahwa terdapat pengaruh yang signifikan antara variabel teman sebaya dan persepsi pola asuh orang tua dengan agresivitas siswa.

\section{PEMBAHASAN}

1. Pengaruh Teman Sebaya $\left(X_{1}\right)$ Terhadap Agresivitas Siswa (Y)

Berdasarkan hasil analisis data yang telah dilakukan dapat disimpulkan bahwa variabel teman sebaya $\left(X_{1}\right)$ berpengaruh terhadap agresivitas siswa (Y). Hal tersebut dapat dilihat dari nilai korelasi antara teman sebaya $\left(\mathrm{X}_{1}\right)$ berpengaruh terhadap agresivitas siswa (Y) atau nilai $r_{x \mid y}=0,396$ dan nilai thitung $>$ $t_{\text {tabel }}=3,584 \geq 1,995$. Hasil ini sama dengan perhitungan menggunakan SPSS 23 yang didapatkan tingkat signifikan sebesar 0,001 yang berarti lebih kecil dari taraf signifikan $5 \%(0,05)$. Besarnya sumbangan kontribusi variabel teman sebaya $\left(X_{1}\right)$ terhadap agresivitas siswa ( $\mathrm{Y}$ ) yaitu sebesar $12,8 \%$ maka rata-rata skor agresivitas siswa $(\mathrm{Y})$ ditentukan oleh teman sebaya $\left(\mathrm{X}_{1}\right)$ sebesar $12,8 \%$ dan sisanya $87,2 \%$ ditentukan oleh faktor lain yang melalu persamaan regresi linear sederhana $\hat{Y}=$ $34,82603+0,4396$ X. Berdasarkan hasil diatas dapat disimpulkan bahwa teman sebaya $\left(X_{1}\right)$ mampu mempengaruhi agresivitas siswa $(\mathrm{Y})$.

Hasil yang serupa dengan penelitian yang dilakukan oleh Adiati Mustikaningsih (2015) yang mendapatkan hasil bahwa kelompok teman sebaya dapat mempengaruhi agresivitas siswa. Monks (1994: 125) menjabarkan faktor-faktor terbetuknya teman sebaya yaitu umur, situasi, keakraban, ukuran kelompok, perkembangan kognitif. Fokus dari penelitian ini yaitu teman sebaya yang terdapat di lingkungan sekolah, karena siswa banyak menghabiskan waktu bersama teman-temannya, setelah pulang sekolah mereka dapat bertemu kembali di lingkungan luar sekolah seperti di lingkungan masyarakat, dengan demikian teman sebaya mempunyai peranan penting dalam pembentukan perilaku yang di dalamnya dapat berupa agresivitas.

Teman sebaya mempunyai sejumlah peran dalam proses perkembangan sosial anak. Peranan tersebut dijabarkan oleh Yusuf (2010:60) yaitu memberikan kesempatan berinteraksi dengan orang lain, mengontrol perilaku sosial, mengembangkan keterampilan dan minat sesuai dengan usianya, dan saling bertukar pikiran dan masalah. Peran teman sebaya juga dikemukakan oleh Santrock (2011:277), teman sebaya dalam proses perkembangan sosial anak antara lain sebagai sahabat, stimulasi, sumber dukungan fisik, sumber dukungan ego, fungsi perbandingan sosial dan fungsi kasih sayang.

2. Pengaruh Persepsi Pola Asuh Orang Tua $\left(\mathrm{X}_{2}\right)$ Terhadap Agresivitas Siswa (Y)

Berdasarkan hasil analisis data yang telah dilakukan dapat disimpulkan bahwa variabel persepsi pola asuh orang tua $\left(\mathrm{X}_{2}\right)$ berpengaruh terhadap 
agresivitas siswa $(\mathrm{Y})$. Hal tersebut dapat dilihat dari nilai korelasi antara persepsi pola asuh orang tua $\left(\mathrm{X}_{2}\right)$ berpengaruh terhadap agresivitas siswa $(\mathrm{Y})$ atau nilai $r_{x \mid y}=0,39689$ dan nilai thitung $>t_{\text {tabel }} 3,913 \geq$ 1,995. Hasil ini sama dengan perhitungan menggunakan SPSS 23 yang didapatkan tingkat signifikan sebesar 0,001 yang berarti lebih kecil dari taraf signifikan 5\% $(0,05)$. Besarnya sumbangan kontribusi variabel persepsi pola asuh orang tua $\left(\mathrm{X}_{2}\right)$ terhadap agresivitas siswa $(\mathrm{Y})$ yaitu sebesar $14,5 \%$ maka rata-rata skor agresivitas siswa $(\mathrm{Y})$ ditentukan oleh persepsi pola asuh orang tua $\left(\mathrm{X}_{2}\right)$ sebesar $14,5 \%$ dan sisanya $85,5 \%$ ditentukan oleh faktor lain yang melalui persamaan regresi linear sederhana $\hat{Y}=28,5075+0,556 X$. Dari hasil diatas dapat disimpulkan bahwa persepsi pola asuh orang tua $\left(\mathrm{X}_{2}\right)$ mampu mempengaruhi agresivitas siswa $(\mathrm{Y})$.

Berdasarkan pengelolaan hasil di atas juga disimpulkan bahwa persepsi pola asuh orang tua yang paling dominan adalah pola asuh acuh tak acuh yaitu dengan presentase $83,87 \%$, pola asuh otoriter, pola asuh permisif dan pola asuh otoritatif. Hasil penelitian yang telah dilakukan serupa dengan penelitian yang dilakukan oleh Suastini (2011, 97-107) yang menunjukkan bahwa terdapat hubungan yang positif antara pola asuh otoriter orang tua dengan agresivitas. Penelitian lain yang dilakukan Aisyah (2010) mendapatkan hasil bahwa bahwa keluarga merupakan sumber bagi timbulnya sifat agresi anak. Faktor yang menjadi penyebab timbulnya tingkah laku agresif adalah kecenderungan pola asuh tertentu dari orang tua.

Sriyanto (2014:74-88) dalam penelitiannya yang berjudul "Perilaku Asertif dan Kecenderungan Kenakalan Remaja Berdasarkan Pola Asuh dan
Peran Media Massa" menunjukkan hasil bahwa pola asuh orang tua berpengaruh signifikan positif terhadap perilaku asertif. Pengaruh positif pola asuh terhadap perilaku asertif dapat dilihat dari orang tua yang menjadi faktor penting dalam pembentukan kepribadian anak. Kepribadian orangtua, sikap dan cara hidupnya merupakan unsur pendidikan yang secara langsung dan tidak langsung menjadi model bagi anaknya.

Keluarga menjadi tempat awal bagi perkembangan siswa. Hubungan yang positif dan sehat biasanya menghasilkan anak yang bahagia, ramah, dianggap menarik oleh orang lain dan relatif bebas dari kecemasan. Berbeda dengan anak yang mempunyai penyesuaian buruk yang biasanya berasal dari pola asuh orang tua yang tidak kurang tepat. Penyesuaian tersebut terjadi karena anak meniru gaya orang tua yang tidak baik atau kurangnya kasih kasih dari orang tua dan mempunyai hubungan yang kurang baik antara orang tua dengan anak.

3. Pengaruh Teman Sebaya $\left(X_{1}\right)$ dan Persepsi Pola Asuh Orang Tua $\left(\mathrm{X}_{2}\right)$ Terhadap Agresivitas Siswa (Y)

Berdasarkan hasil analisis data yang telah dilakukan dapat disimpulkan bahwa variabel teman sebaya $\left(\mathrm{X}_{1}\right)$ dan persepsi pola asuh orang tua $\left(\mathrm{X}_{2}\right)$ berpengaruh terhadap agresivitas siswa (Y). Hal tersebut dapat dilihat dari nilai korelasi ganda antara teman sebaya $\left(\mathrm{X}_{1}\right)$ dan persepsi pola asuh orang tua $\left(\mathrm{X}_{2}\right)$ berpengaruh terhadap agresivitas siswa (Y) atau nilai $\left(R_{X_{1} X_{2} Y}\right)=0,468$ dan nilai $F_{\text {hitung }} \geq F_{\text {tabel }}$ yaitu $9,534 \geq 3,132$. Hasil ini sama dengan perhitungan menggunakan SPSS 23 yang didapatkan tingkat signifikan sebesar 0,000 yang berarti lebih kecil dari taraf signifikan $5 \% \quad(0,05)$. Besarnya sumbangan kontribusi variabel teman sebaya $\left(\mathrm{X}_{1}\right)$ 
dan persepsi pola asuh orang tua $\left(\mathrm{X}_{2}\right)$ secara bersama-sama terhadap agresivitas siswa ( $\mathrm{Y}$ ) yaitu sebesar 18,8\% maka rata-rata skor agresivitas siswa $(\mathrm{Y})$ ditentukan oleh teman sebaya $\left(\mathrm{X}_{1}\right)$ dan persepsi pola asuh orang tua $\left(\mathrm{X}_{2}\right)$ sebesar $18,8 \%$ dan sisanya $81,2 \%$ ditentukan oleh faktor lain yang melalui persamaan regresi linear ganda $\widehat{Y}=a+$ $\mathrm{b}_{1} \mathrm{X}_{1}+\mathrm{b}_{2} \mathrm{X}_{2}=15.843+0,306 \mathrm{X}_{1}+$ $0,388 \mathrm{X}_{2}$. Dari hasil diatas dapat disimpulkan bahwa terdapat pengaruh yang signifikan antara teman sebaya $\left(\mathrm{X}_{1}\right)$ dan persepsi pola asuh orang tua $\left(X_{2}\right)$ terhadap agresivitas siswa (Y).

Penelitian ini diperkuat oleh penelitian yang dilakukan oleh Zhafarina yang mendapatkan hasil bahwa terdapat hubungan positif antara konformitas teman sebaya dengan perilaku agresif pada remaja yaitu nilai $r x y=0,326$ dengan $p<0,01$. Agresivitas siswa tidak hanya dipengaruhi oleh teman sebaya namun juga dari keluarga. Pada penelitian yang dilakukan oleh $\mathrm{R}$. Rachmy Diana mendapatkan hasil bahwa terdapat hubungan antara Komunikasi Remaja-Orangtua dengan Agresivitas Pelajar.

Ormrod (2008:176) meyatakan bahwa agresivitas dapat disebabkan oleh faktor internal maupun eksternal. Faktor internal berasal dari diri sendiri atau dari diri seseorang, sedangkan faktor eksternal meliputi keluarga, sekolah dan teman sebaya. Faktor eksternal mempunyai pengaruh agresivitas yang berbeda-beda, tinggi rendahnya agresivitas dapat dikarenakan dukungan yang mereka dapat dari lingkungannya.

\section{PENUTUP}

1. Simpulan

Berdasarkan hasil penelitian dan analisis data, maka diperoleh kesimpulan yaitu: 1) terdapat pengaruh yang signifikan antara teman sebaya terhadap agresivitas siswa di sekolah dasar; 2) terdapat pengaruh yang signifikan antara persepsi pola asuh orang tua terhadap agresivitas siswa di sekolah dasar; 3) terdapat pengaruh yang signifikan antara teman sebaya dan persepsi pola asuh orang tua terhadap agresivitas siswa di sekolah dasar.

2. Saran

Berdasarkan hasil penelitian dan analisis data, maka dapat di sarankan : 1) siswa seharusnyanya dapat membedakan perilaku yang baik dan yang tidak baik, dan dapat menyaring perilaku yang bisa dicontoh, serta dapat berperilaku sesuai dengan norma dan aturan yang berlaku; 2) orang tua hendaknya memantau perkembangan anak dan memberi contoh yang baik kepada anakanaknya; 3) guru hendaknya lebih meningkatkan komunikasi dengan siswa dan orang tua agar terjalin kerja sama dalam hal membimbing dan mendidik anak; 4) sekolah dapat mengadakan kegiatan yang berkaitan dengan akhlak dan norma guna mencegah atau mengurangi perilaku siswa yang kurang baik; 5) peneliti selanjutnya yang ingin meneliti dengan tema yang sama, diharapkan dapat mengkaitkan dengan variabelvariabel lain dan mengkaji lebih dalam lagi tentang teman sebaya dan persepsi pola asuh orang tua terhadap agresifitas siswa.

\section{DAFTAR PUSTAKA}

[1] Aisyah. (2010). Pengaruh Pola Asuh Orang Tua terhadap Tingkat Agresivitas Anak. Jurnal Medtek Vol 2 No 1.

Makasar 


\section{Jurnal \\ ISSH SAINS SOSIAL dan HUMANIORA}

[2] Buss, H. and Mark P. (1992). The Aggression Questionnaire. Journal of Personality and Social Psychology Vol. 63. No.3, Austin

[3] Desmita. (2005). Psikologi Perkembangan. Bandung: Rosdakarya

[4] Monks, dkk (1994). Psikologi Perkembangan: Pengantar Dalam Berbagai Bagiannya. Yogyakarta: Gajah Mada University

[5] Mustikaningsih, Adiati, dkk. (2015). Pengaruh Fungsi Kelompok Teman Sebaya terhadap Perilaku Agresivitas Siswa di SMA N 3 Klaten. Jurnal Bimbingan Konseling Vol 1 No 1. Yogyakarta

[6] Ormrod, JE. (2008) Psikologi Pendidikan : Membantu Siswa Tumbuh dan Berkembang. Jakarta: Erlangga

[7] Rakhmat, J. (2011). Psikologi Komunikasi. Bandung: Rosdakarya
[8] Santosa, E. (2015). Raising Children In Digital Era. Jakarta: Gramedia

[9] Santrock, J. (2011). Masa Perkembangan Anaka Jilid 1. Jakarta: Salemba

[10] Sriyanto, Aim Abdul Karim, Azmawi Zainul, EnokMaryani. (2014). "Perilaku Asertif dan Kecenderungan Kenakalan Remaja Berdasarkan Pola Asuh dan Peran Media Massa". Jurnal Psikologi Vol 41, No 1. Hal 74-88. http://doi.org/10.22146/jpsi.6059

[11] Suastini, Ni Wayan. (2011). Hubungan Antara Pola Asuh Otoriter dengan Agresivitas Remaja. Jurnal Bimbingan Konseling Vol 1 No 1. Denpasar

[12] Sugihartono, dkk. (2013). Psikologi Pendidikan. Yogyakarta: UNY Press

[13] Yosep. (2007). Perkembangan Jiwa. Bandung: Rosdakarya

[14] Zhafarina. (2014). Perilaku Agresif Remaja Ditinjau Dari Konformitas Teman Sebaya. Jurnal Psikologi. Universitas Negeri Semarang 